Wahana Didaktika Vol. 18 No.3 September 2020 : 270-279

\title{
ANALISIS TINGKAT KEMAMPUAN BERPIKIR KREATIF MATEMATIKA SISWA SMA NEGERI 1 CIRUAS KOTA SERANG PADA MATERI GEOMETRI
}

\author{
Oleh: Fita Nofiana Arda, Heni Pujiastuti \\ Email : fitaarda@gmail.com, henipujiastuti@untirta.ac.id \\ (Universitas Sultan Ageng Tirtayasa)
}

\begin{abstract}
Abstrak
Tujuan dari penelitian ini adalah untuk menganalisis tingkat kemampuan berpikir kreatif siswa kelas XI SMA Negeri 1 Ciruas ditinjau dari kemampuan awal siswa pada materi geometri dengan pengklasifikasian Tingkat Kemampuan Berpikir Kreatif (TKBK) berdasarkan kriteria kefasihan, fleksibilitas dan kebaruan. Penelitian yang dilakukan adalah penelitian deskriptif kualitatif. Pengambilan subjek menggunakan teknik purposive sampling. Subjek penelitian 6 siswa kelas XI SMA Negeri 1 Ciruas. Instrumen yang digunakan dalam penelitian ini berupa 5 butir soal tes tertulis berbentuk uraian materi geometri. Berdasarkan Hasil penelitian tingkat kemampuan berpikir kreatif dari 6 siswa diperoleh 2 siswa dengan kemampuan berpikir awal tinggi berada pada TKBK 4 (sangat kreatif), 3 siswa dengan kemampuan awal sedang berada pada TKBK 3 (kreatif) sebanyak 2 siswa dan TKBK 2 (cukup kreatif) sebanyak 1 siswa serta 1 siswa dengan kemampuan awal rendah berada pada TKBK 0 (tidak kreatif). Semakin tinggi kemampuan awal siswa maka semakin tinggi tingkat kemampuan berpikir kreatif yang dimilikinya, jika semakin rendah kemampuan awal siswa maka semakin rendah juga tingkat kemampuan berpikir kreatifnya.
\end{abstract}

Kata Kunci : Geometri, Kemampuan Awal, Tingkat Kemampuan Berpikir Kreatif

\section{ANALYSIS OF MATHEMATICS CREATIVE THINKING ABILITY LEVEL OF STUDENTS OF CIRUAS HIGH SCHOOL 1 SERANG CITY IN GEOMETRY MATERIALS}

\begin{abstract}
The purpose of this study was to analyze the level of creative thinking ability of class XI students at SMA Negeri 1 Ciruas in terms of students' initial abilities in geometry material by classifying Creative Thinking Ability Levels (TKBK) based on criteria for fluency, flexibility and novelty. The research conducted was a qualitative descriptive study. Taking the subject using purposive sampling technique. Research subjects are 6th grade students of SMA Negeri 1 Ciruas. The instruments used in this study were 5 written test items in the form of geometrical material descriptions. Based on the results of research on the level of creative thinking ability of 6 students obtained 2 students with high initial thinking ability are at TKBK 4 (very creative), 3 students with initial ability are at TKBK 3 (creative) as many as 2 students and TKBK 2 (quite creative) as many as 1 student and 1 student with low initial ability are at TKBK 0 (not creative). The higher the initial ability of students, the higher the level of creative thinking
\end{abstract}


Analisis Tingkat Kemampuan Berpikir.... (Fita Nofiana Arda, Heni Pujiastuti)

abilities they have, the lower the initial ability of students, the lower the level of creative thinking abilities.

Keywords: Geometry, Early Ability, Level of Creative Thinking Ability

\section{A. PENDAHULUAN}

Matematika merupakan ilmu yang harus dipelajari pada setiap jenjang pendidikan. Terdapat karakteristik matematika, yaitu: 1) Memiliki objek kajian yang abstrak, 2) Berpola piker deduktif, 3) Mengacu pada kesepakatan, 4) Konsisten dalam sistemnya, 5) Memiliki simbol yang kosong dari arti, 6) memperhatikan semesta pembicaraan. Dalam mempelajari matematika diperlukan kreativitas. Kreativitas memainkan peran penting dalam siklus berrpikir matematis tingkat lanjut (Ervync, 1991).

Berpikir merupakan suatu kegiatan otak yang dilakukan seseorang baik secara sadar maupun tidak sadar. Presseisen (Somakim, 2010) mengartikan bahwa berpikir adalah proses kognitif yaitu suatu aktivitas mental yang menekankan penalaran untuk memperoleh pengetahuan. Menurut Ruggiero (Siswono, 2008) berpikir adalah suatu aktivitas mental untuk memecahkan suatu masalah, membuat suatu keputusan, atau memenuhi hasrat keingintahuan.

Berpikir berkaitan erat dengan apa yang terjadi di dalam otak manusia dan fakta yang ada pada dunia sehingga bisa divisualisasikan serta berpikir bisa diobservasi dan dikomunikasikan (Suryadi, 2005). Dalam pemecahan masalah apabila anak dapat menerapkan berpikir kreatif, maka akan menghasilkan banyak ide yang berguna dalam menemukan penyelesaian masalah (Siswono, 2008), jadi berpikir kreatif yaitu proses berpikir yang menghasilkan berbagai macam kemungkinan jawaban. Proses kreatif dalam pengembangan gagasan dalam mampu menciptakan suatu topik tulisan dengan cara yang berbeda (Armariena \& Murniviyanti, 2017, p. 100). Kemampuan berpikir kreatif matematis yang diukur berdasarkan kriteria kefasihan, fleksibilitas, dan kebaruan (Siswono, 2008).

Tingkat berpikir kreatif matematis siswa di Indonesia masih kurang. Berdasarkan survei hasil tes dan evaluasi PISA tahun 2015 rata-rata skor pencapaian Matematika Indonesia berada pada peringkat 63 dari 69 negara yang 
dievaluasi. Diperkuat oleh hasil survei internasional Trend in International Mathematic and Science Study (TIMSS) 2011 (Firdausi dan Wuryanto, 2018:240) bahwa di bidang matematika pada siswa kelas VIII SMP, Indonesia berada pada peringkat 38 dari 42 negara dengan skor rata-rata 386, sedangkan skor rata-rata internasional 500.

Sisk (Machromah, Riyadi dan Usodo, 2015:613-614) menyatakan pembelajaran matematika masih didominasi oleh pengenalan rumus-rumus serta konsep secara verbal, tanpa ada perhatian yang cukup pada pemahaman siswa. Pada proses pembelajaran matematika dinilai belum menekankan pada pengembangan daya nalar, logika, dan proses berpikir siswa. Metode pembelajaran tersebut mengakibatkan kurangnya kreativitas siswa dalam menyelesaikan permasalahan non rutin. Kebanyakan siswa cenderung lebih mengikuti prosedur sesuai dengan apa di dapatkannya dalam pembelajaran, siswa tidak mau untuk mencari solusi baru yang berbeda untuk menyelesaikan permasalahan matematika.

Salah satu cara yang diperkirakan dapat menumbuhkan kreativitas matematika pada siswa adalah dengan memberikan permasalahan-permasalahan berbasis kemampuan berpikir kreatif yaitu dengan memberikan suatu permasalahan materi geometri. Geometri merupakan salah satu bagian dari matematika yang dipelajari di sekolah. Endorgan (2009) menyatakan bahwa geometri merupakan salah satu bidang penting dari matematika yang memiliki efek pada pengembangan keterampilan berpikir kreatif peserta didik dalam pembelajaran matematika. Menurut Hidayat (2013) sebagian besar peserta didik hanya mengandalkan hafalan tanpa memahami konsep geometri sehingga siswa cenderung membuat kesalahan dalam menyelesaikan soal.

Beberapa fakta di lapangan menunjukkan hasil belajar geometri siswa di Indonesia masih rendah. Salah satunya berdasarkan laporan TIMSS tahun 2011. Nilai rata-rata untuk materi geometri adalah 377. Indonesia menduduki peringkat tiga terbawah dari negara-negara peserta TIMSS yang lain dan hal ini menunjukkan bahwa kemampuan siswa dalam mengerjakan soal-soal geometri masih rendah. 
Kemampuan berpikir kreatif matematis yang diukur berdasarkan kriteria kefasihan, fleksibilitas, dan kebaruan (Siswono, 2009:9).

Tabel 1. Deskripsi Indikator Kemampuan Berpikir Kreatif

\begin{tabular}{|l|l|}
\hline \multicolumn{1}{|c|}{ Indikator } & \multicolumn{1}{c|}{ Kriteria Kemampuan } \\
\hline Kefasihan & $\begin{array}{l}\text { Siswa mampu menyelesaikan masalah dengan beragam } \\
\text { (lebih dari satu) jawaban masalah yan bernilai benar. }\end{array}$ \\
\hline Fleksibilitas & $\begin{array}{l}\text { Siswa mampu memecahkan masalah dengan berbagai cara } \\
\text { yang berbeda. }\end{array}$ \\
\hline Kebaruan & $\begin{array}{l}\text { Siswa mampu membuat suatu penyelesaian yang baru yang } \\
\text { belum pernah dilakukan oleh individu lainnya. }\end{array}$ \\
\hline
\end{tabular}

Berikut ini akan disajikan lima karakteristik tingkat kemampuan berpikir kreatif menurut Siswono (2009, p.9).

1. TKBK 4 (sangat kreatif)

Pada tingkat ini siswa disebut dengan siswa yang sangat kreatif apabila siswa mampu menyelesaikan suatu permasalahan dengan memberikan lebih dari satu alternatif jawaban serta cara penyelesaian yang berbeda-beda dengan lancar (fasih) dan fleksibel.

2. TKBK 3 (kreatif)

Pada tingkat ini siswa disebut dengan siswa yang kreatif apabila siswa mampu memberikan suatu jawaban baru dengan cara penyelesaian yang berbeda (fleksibel) meski tidak fasih.

3. TKBK 2 (cukup kreatif)

Pada tingkat ini siswa disebut dengan siswa yang cukup kreatif apabila siswa mampu membuat satu jawaban penyelesaian masalah yang bebeda meskipun tidak fleksibel atau siswa mampu menunjukkan bermacam cara penyelesaian yang berbeda dengan lancar meskipun jawaban yang dihasilkan tidak baru.

4. TKBK 1 (kurang kreatif)

Pada tingkat ini siswa disebut dengan siswa yang kurang kreatif apabila siswa tidak mampu membuat satu jawaban atau penyelesaian masalah yang bebeda dan baru meskipun cara penyelesaiannya fasih. 
5. TKBK 0 (tidak kreatif)

Pada tingkat ini siswa disebut dengan siswa yang tidak kreatif apabila siswa tidak mampu membuat alternatif jawaban maupun cara penyelesaian masalah yang bebeda, baru dan fasih.

Basically, creative writing builds on two important elements of writing as a skill and creativity as a mentality that tends to create (Armariena, 2017, p. 853). Berdasarkan uraian di atas, dapat dibuat pedoman pengklasifikasian Tingkat Kemampuan Berpikir Kreatif (TKBK) berdasarkan kriteria kefasihan, fleksibilitas dan kebaruan. Pedoman pengklasifikasian TKBK dapat dilihat pada Tabel dibawah ini.

Tabel 2. Pedoman Pengklasifikasian TKBK

\begin{tabular}{|c|c|c|c|c|c|c|c|c|}
\hline Indikator & TKB & \multicolumn{3}{|c|}{ TKBK 3 } & \multicolumn{2}{c|}{ TKBK } & TKB & TKBK \\
K 1 & 0 \\
\hline Kefasihan & $\sqrt{ }$ & $\sqrt{ }$ & $\sqrt{ }$ & - & - & - & $\sqrt{ }$ & - \\
\hline Fleksibilitas & $\sqrt{ }$ & - & $\sqrt{ }$ & $\sqrt{ }$ & $\sqrt{ }$ & - & - & - \\
\hline Kebaruan & $\sqrt{ }$ & $\sqrt{ }$ & - & $\sqrt{ }$ & - & $\sqrt{ }$ & - & - \\
\hline
\end{tabular}

Berdasarkan Pernyataan diatas maka peneliti tertarik untuk melakukan penelitian dengan judul Analisis Tingkat Kemampuan Berpikir Kreatif Matematika Siswa Kelas XI SMA Negeri 1 Ciruas Kota Serang Pada Materi Geometri.

\section{B. METODOLOGI PENELITIAN}

Penelitian ini menggunakan pendekatan kualitatif dengan metode deskriptif bertujuan untuk memperoleh data maupun informasi untuk menganalisis atau menggambarkan kemampuan berpikir kreatif siswa kelas XI SMA Negeri 1 Ciruas ditinjau dari kemampual awal berpikir kreatif siswa pada materi geometri. Penelitian ini dilaksanakan di SMA Negeri 1 Ciruas Kota Serang. Teknik pengambilan sampel menggunakan Purposive sampling yaitu menentukan sampel dengan berbagai pertimbangan tertentu untuk mendapatkan sebanyak mungkin informasi yang dibutuhkan. 
Subjek dalam penelitian ini adalah siswa kelas XI SMA Negeri 1 Ciruas dimana nanti akan diambil sampel sebanyak 6 siswa. Instrumen yang digunakan dalam penelitian ini adalah tes tertulis berupa soal uraian sebanyak 5 soal tentang materi geometri. Aspek yang diukur pada penelitian ini adalah 1) Kelancaran, kemampuan siswa dalam menghasilkan banyak alternatif jawaban dan menyelesaikan permasalahn secara lancar, terdapat pada butir soal nomor 1 dan 2 , 2) Fleksibel, kemampuan siswa dalam menyajikan beberapa cara yang berbeda untuk menyelesaikan permasalahan, terdapat pada butir soal nomor 3 dan 4, 3) Kebaruan.

Teknik pengumpulan data pada penelitian ini adalah tes dan wawancara. Teknik analisis data yang dipakai dalam penelitian ini adalah Teknik analisis data Miles dan Huberman yaitu reduksi data, penyajian data dan penarikan kesimpulan (Sugiyono, 2015:338). Analisis data dilakukan dengan menganalisis data hasil tes yang dilakukan siswa. Analisis data hasil tes memperhatikan indikator kefasihan, fleksibilitas, dan kebaruan. Analisis dilakukan pada jawaban dan langkah-langkah penyelesaian yang digunakan siswa dalam menjawab permasalahan yang diberikan.

Penentuan subyek dalam penelitian ini diklasifikasikan berdasarkan kemampuan awal tingkat tinggi, sedang dan rendah melalui tes awal kemampuan pengetahuan siswa. Kedudukan tinggi, sedang dan rendah ditentukan dengan menggunakan penilaian acuan patokan (PAP) yang dimodifikasi sebagai berikut:

Tabel 3. PAP Kemampuan Awal Peserta Didik

\begin{tabular}{|c|c|}
\hline Skor & Kategori \\
\hline $25<$ skor $\leq 35$ & Tinggi \\
\hline $15<$ skor $\leq 25$ & Sedang \\
\hline $0<$ skor $\leq 15$ & Rendah \\
\hline
\end{tabular}

\section{HASIL PENELITIAN DAN PEMBAHASAN}

Berdasarkan kriteria penilaian acuan patokan diperoleh 2 siswa dengan kemampuan awal tinggi, 3 siswa dengan kemampuan awal sedang dan sebanyak 1 siswa dengan kemampuan awal rendah. Berikut akan disajikan deskripsi hasil pekerjaan keempat siswa tersebut: 
Tabel 4. Subjek Penelitian

\begin{tabular}{|c|l|c|c|}
\hline No & Subjek Terpilih & Nilai & TKBK \\
\hline 1 & TMRS & 33 & 4 \\
\hline 2 & HV & 28 & 4 \\
\hline 3 & KM & 24 & 3 \\
\hline 4 & KAP & 20 & 3 \\
\hline 5 & NH & 16 & 2 \\
\hline 6 & A & 10 & 0 \\
\hline
\end{tabular}

1. Tingkat Kemampuan Berpikir Kreatif (TKBK) Kemampuan Awal Tinggi

a) TKBK 4 (Sangat Kreatif)

TMRS dan HV mampu menyelesaikan suatu masalah dengan lancar (fasih), dapat menyelesaikan permasalahan dengan cara penyelesaian yang berbeda (fleksibel) dan mampu menunjukkan metode yang baru yang berbeda (kebaruan). TMRS dan HV menyatakan bahwa tidak ada kesulitan saat mengerjakan soal tes kemampuan berpikir kreatif. Dapat disimpulkan bahwa siswa dengan kemampuan berpikir kreatif tinggi adalah siswa yang mampu menyelesaikan suatu permasalahan secara fasih (lancar), fleksibel, dan kebaruan.

2. Tingkat Kemampuan Berpikir Kreatif (TKBK) Kemampuan Awal Sedang

a) TKBK 3 (Kreatif)

KM dan KAP mampu menyelesaikan suatu masalah dengan lancar (fasih) serta dapat menyelesaikan permasalahan dengan cara penyelesaian yang berbeda (fleksibel) walaupun tidak menunjukkan metode yang baru yang berbeda. KM dan KAP menunjukkan cara yang salah dalam menunjukkan kebaruan, sehingga dapat dikatakan mereka berdua tidak dapat membuat penyelesaian yang berbeda.

b) TKBK 2 (Cukup Kreatif)

NH mampu menunjukkan metode yang baru yang berbeda (kebaruan) namun tidak mampu menyelesaikan permasalahan dengan cara penyelesaian yang berbeda (fleksibel) serta tidak lancar (fasih) dalam menyelesaikan permasalahan. $\mathrm{NH}$ menyatakan hanya mampu membuat 
Analisis Tingkat Kemampuan Berpikir.... (Fita Nofiana Arda, Heni Pujiastuti)

penyelesaian dengan satu cara yang berbeda dan tidak mampu menyelesaikannya dengan lebih dari satu cara.

3. Tingkat Kemampuan Berpikir Kreatif (TKBK) Kemampuan Awal Rendah

a) TKBK 1 (Kurang Kreatif)

A mampu menyelesaikan permasalahan dengan lancar (fasih), namun tidak mampu menunjukkan metode yang baru yang berbeda (kebaruan) dan tidak mampu menyelesaikan permasalahan dengan cara penyelesaian yang berbeda (fleksibel). A menyatakan kesulitan ketika diminta utuk menunjukkan cara yang berbeda dan metode yang baru. Disimpulkan, siswa dengan kemampuan awal rendah hanya mampu berpikir secara fasih, tidak mampu berpikir secara fleksibel dan kebaruan. Jadi, siswa dengan kemampuan awal rendah tidak mampu mengembangkan kemampuan berpikir kreatif.

Berdasarkan Penelitian Leikin dan lev (2013) terdapat hubungan antara kemampuan matematika yang tinggi dengan kreativitas matematika. Jadi, sesuai dengan penelitian ini semakin tinggi kemampuan awal siswa maka semakin tinggi tingkat kreativitasnya. Hasil penelitian ini sejalan dengan hasil penelitian oleh Septianingrum, Setiawani, dan Diah (2015) yaitu siswa dengan kemampuan awal tinggi berada pada TKBK 4, siswa dengan kemampuan awal sedang berada pada TKBK 3, dan TKBK 2, sedangkan siswa dengan kemampuan awal rendah berada pada TKBK 0 .

\section{SIMPULAN}

Berdasarkan hasil penelitian yang diperoleh, dan setelah melakukan analisis data, maka dapat disimpulkan secara umum bahwa untuk mengetahui tingkat kreativitas berpikir seorang siswa dapat dilakukan dengan cara memberikan tes kemampuan di awal pembelajaran. Temuan penelitian ini adalah Terdapat perbedaan antara siswa yang berkemampuan matematika tinggi, sedang dan rendah terhadap kemampuan berpikir kreatif matematisnya ditinjau dari kemampuan awal. Sebanyak 2 siswa dengan kemampuan awal tinggi memiliki tingkat kemampuan berpikir kreatif tingkat 4 yaitu sangat kreatif, 3 siswa dengan 
kemampuan awal sedang masing-masing ada di TKBK 3 (Kreatif) sebanyak 2 siswa dan TKBK 2 (Cukup Kreatif) sebanyak 1 siswa, dan sebanyak 1 siswa dengan kemampuan awal rendah berada pada TKBK 0, pada saat mengerjakan soal masih banyak siswa yang cenderung kurang teliti dalam mencermati soal yang diberikan.

Pada hakikatnya berpikir kreatif tidak harus selalu memunculkan atau membuat ide baru, namun lebih condong kearah menggabungkan pengetahuanpengetahuan yang dimiliki. Sesuai dengan definisi berpikir kreatif menurut Suryadi (Widodo, 2010, p.7) yaitu kemampuan untuk mengungkap hubunganhubungan baru, melihat sesuatu dari sudut pandang baru, dan membentuk kombinasi baru dari dua konsep atau lebih yang sudah dikuasai sebelumnya.

\section{DAFTAR PUSTAKA}

Armariena, D. N. (2017). The Theme Based On The Local Wisdom of South Sumatra In The Creative Writing Process. Internasional Conference on Education and Science (ICONS) (pp. 852-854). Jakarta: Pengurus Besar PGRI.

Armariena, D. N., \& Murniviyanti, L. (2017). Penulisan Cerpen Berbasis Kearifan Lokal Sumatera Selatan dengan Metode Image Streaming dalam Proses Kreatif Mahasiswa. Jurnal PEMBAHSI (Pembelajaran Bahasa dan Sastra Indonesia), 7(1), 88-115.

Erdogan, T., et al. (2009). "The Effect of the Van Hiele Model Based Instruction on the Creative Thinking Levels of 6th Grade Primary School Students". Educational Sciences: Theory \& Practice. 9(1), pp. 181-194.

Ervynck, G. (1991). Mathematical Creativity. In Advanced Mathematical Thinking (pp. 42-53). Springer, Dordrecht.

Firdausi, Y.N., Asikin, M., dan Wuryanto. (2018). Analisis Kemampuan Berpikir Kreatif Siswa Ditinjau dari Gaya Belajar pada Pembelajaran Model Eliciting Activities (MEA). Prosiding Seminar Nasional Matematika.

Hidayat, Sholeh. (2013). Pengembangan Kurikulum Baru. Bandung: PT Remaja Rosdakarya Bandung

Leikin, R. \& Lev, M. (2013). Multiple Solution Task as a Magnifying Glass for Observation of Mathematical Creativity. Proceedings of the 31st Conference of the International Group for the Psychology of Mathematics Education. Vol. 3, pp 161-168. 
Machromah, I.U., Riyadi, dan Usodo, B., (2015), Analisis Proses dan Tingkat Berpikir Kreatif Siswa SMP dalam Pemecahan Masalah Bentuk Soal Cerita Materi Lingkaran Ditinjau dari Kecemasan Matematika, Jurnal Elektronik Pembelajaran Matematika, Volume 3 No. 6, Hal 613-624.

Septianingrum, M.F., Setiawani, S. \& Diah, N. (2015). Analisis Tingkat Kemampuan Berpikir Kreatif Siswa Dalam Mengajukan Masalah Matematika Berdasarkan Kemampuan Matematika Kelas XI MIA-G SMA Negeri 1 Probolinggo. Artikel Ilmiah Mahasiswa, 2015, I (1):1-4. Universitas Jember : Fakultas Keguruan dan Ilmu Pendidikan.

Siswono, T. Y. E. (2008). Model Pembelajaran Matematika Berbasis Pengajuan dan Pemecahan Masalah untuk Meningkatkan Kemampuan Berfikir Kreatif. Surabaya: Unesa Press.

Siswono, T. Y. E. (2009). Upaya Meningkatkan Kemampuan Berpikir Kreatif Siswa melalui Pengajuan Masalah. Jurnal Pendidikan Matematika dan Sains, (Online), Tahun X Nomor 1:1-9.

Somakim. (2010). Peningkatan Kemampuan Berpikir Kritis dan Self-Efficacy Matematik Siswa Sekolah Menengah Pertana dengan Penggunaan Pendekatan Matematika Realistik. Desertasi : SPS UPI. Tidak diterbitkan.

Sugiyono. (2015). Metode Penelitian Pendidikan. (Pendekatan Kuantitatif, Kualitatif, dan $R \& D$ ): Bandung: Alfabeta.

Suryadi, D. (2005). Penggunaan Pendekatan Pembelajaran Tidak Langsung serta Pendekatan Gabungan Langsung dan Tidak Langsung dalam Rangka Meningkatkan Kemampuan Matematik Tingkat Tinggi Siswa SLTP. Disertasi, Sekolah Pascasarjana, Universitas Pendidikan Indonesia. 